\title{
Exploitation of nuclear and cytoplasm variability in Hordeum chilense for wheat breeding
}

\author{
Cristina Rodríguez-Suárez ${ }^{1}$, María J. Giménez ${ }^{1}$, María C. Ramírez ${ }^{1}$, \\ Azahara C. Martín ${ }^{1,2}$, Natalia Gutierrez² ${ }^{2}$ Carmen M. Ávila², \\ Antonio Martín ${ }^{1}$ and Sergio G. Atienza ${ }^{1 *}$ \\ ${ }^{1}$ Plant Breeding Department, IAS-CSIC, Apdo. 4084, E-14080, Córdoba, Spain and \\ ${ }^{2}$ Área Mejora y Biotecnología, IFAPA-Centro Alameda del Obispo, Córdoba, Spain
}

\begin{abstract}
Hordeum chilense Roem. et Schultz. is a diploid wild barley native to Chile and Argentina. The high crossability of this species with other members of the Triticeae tribe promoted the development of the new species $\times$ Tritordeum Ascherson et Graebner. Hexaploid tritordeum was developed from the hybrid derived from the cross between $H$. chilense (used as female parent) and durum wheat. The interest of $H$. chilense is based on the presence of traits potentially useful for wheat breeding, including high endosperm carotenoid content, septoria tritici blotch resistance and abiotic stress tolerance. Besides, the variability at cytoplasm level is also important in this species. The development of common wheat $-H$. chilense alloplasmic lines (nucleus from wheat and cytoplasm from $H$. chilense) results in fertile or male sterile genotypes, depending on the accession donating the cytoplasm. Furthermore, these alloplasmic lines constitute an ideal system for deepening our knowledge on nuclear-cytoplasm interactions. In conclusion, $H$. chilense is an interesting source of variability for wheat breeding.
\end{abstract}

Keywords: cytoplasm; Hordeum chilense; plant breeding; plasmon; wild relatives

\section{Wild relatives for crop breeding: potential of nuclear variability in Hordeum chilense Roem. et Schultz}

The progressive narrowing of the genetic base in crops (Tanksley and McCouch, 1997; Warburton et al., 2006) has promoted a renewed interest in wild relatives such as Hordeum vulgare ssp. spontaneum (Matus et al., 2003; Inostroza et al., 2009) or other distant relatives such as Aegilops tauschii, donor of the D genome of common wheat (van Ginkel and Ogbonnaya, 2007); or H. chilense Roem. et Schultz. (Atienza et al., 2000; Atienza et al., 2005b; Martin et al., 2008b). The wild barley $H$. chilense shows a wide range of variation

*Corresponding author. E-mail: sgatienza@ias.csic.es (at both morphological and molecular levels) distributed into two main groups plus an intermediate group, as revealed by molecular markers (Vaz Patto et al., 2001; Castillo et al., 2010). The high compatibility of $H$. chilense with the genomes of Triticum species gives rise to fertile and stable amphiploids and allows the transfer of traits to wheat (Martin et al., 1998), such as resistance to septoria tritici, abiotic stress tolerance or endosperm storage proteins (Martin et al., 1999; Atienza et al., 2002), but probably the main interest of this species is its potential for increasing carotenoid content (Alvarez et al., 1999; Atienza et al., 2004; Atienza et al., 2005a; Atienza et al., 2007b). The phytoene synthase 1 from $H$. chilense is a good candidate gene for the improvement of carotenoid content (Atienza et al., 2007a), and, therefore, the cloning and characterization of this gene offer new possibilities for wheat breeding (Rodriguez-Suarez et al., 2010). Similarly, the development of $H$. chilense durum 
wheat chromosome substitution lines will be useful for evaluating the substitution effect of durum wheat by $H$. chilense genes for carotenoid content. The use of barley expressed sequence tag (EST) markers (Hagras et al., 2005a; Hagras et al., 2005b; Nasuda et al., 2005) has proven very useful for physical mapping in $H$. chilense (Atienza et al., 2007c; Said and Cabrera, 2009; Cherif-Mouaki et al., 2011). Besides, the development of the genetic linkage map using ESTs, conserved orthologous set (Bolot et al., 2009) and $H$. chilense-specific diversity arrays technology markers will allow the establishment of precise relationships between $H$. chilense and related species genomes, thus providing more efficient tools for the use of this wild barley in wheat breeding.

\section{Cytoplasm $\times$ nuclear variability in $H$. chilense- wheat interactions}

The nuclear genome has a predominating role for the inheritance of most plant traits Nevertheless, cytoplasmic factors and cytoplasm $\times$ nucleus interactions are also important and still largely unexplored. Genetic information of eukaryotic organisms is divided into a nuclear genome in the nucleus and organelle genomes (sometimes referred to as plasmon) in the cytoplasm. Since the cytoplasm is maternally inherited in Triticeae species (Kihara, 1951), the best way to investigate nuclear-cytoplasm interactions is by developing alloplasmic lines, i.e. lines with the same nucleus but cytoplasms from different species.

H. chilense-wheat alloplasmic lines have been developed by repeated substitution backcross as described by Kihara (1951). First, amphiploids H. chilense $\times$ wheat are developed as described by Martin and Chapman (1977). This step is essential since the hybrids between $H$. chilense and wheat are sterile while the amphiploids are fertile. Backcrossing to the nucleus donor is repeated until $H$. chilense chromosomes are fully eliminated. After somatic chromosome counting, the cytoplasm origin has to be checked, since paternal inheritance of cytoplasm has also been reported (Soliman et al., 1987; Laser et al., 1997; Aksyonova et al., 2005; Badaeva et al., 2006). Indeed, we have observed this phenomenon with both H. chilense (Atienza et al., 2007d) and H. vulgare cytoplasms (Martin et al., 2008a) using the chloroplastic marker cCSSR 4 (Chung and Staub, 2003).

Alloplasmic lines are very useful for elucidating plant phylogeny and determining the genetic effect of different plasmons. Furthermore, since the discovery of cytoplasmic male sterility (CMS) in wheat (Kihara, 1951), breeders have been very interested in CMS systems, looking for a viable procedure for hybrid wheat production (for a review, see Martin, 2009).
The development of $H$. chilense-common wheat alloplasmic lines gives rise to two types of lines: male-sterile when the line $\mathrm{H} 1$ is used as cytoplasm donor, or fully fertile when other $H$. chilense lines are used. Accordingly, a research line is being developed to investigate the potential of this new CMS source, designated $\mathrm{msH} 1$, to produce hybrid wheat. The male sterile line does not show any floral or developmental abnormalities, but reduced height and delayed heading (Martin et al., 2008b). Fertility restoration is obtained when chromosome $6 \mathrm{H}^{\mathrm{ch}} \mathrm{S}$ from $H$. chilense line $\mathrm{H} 1$ is added (Martin et al., 2008b). Further research allowed the obtaining of a fertile euplasmic line carrying the translocation T6Hchs.6DL (Martin et al., 2009). However, a single dose of this translocation is insufficient for fertility restoration, which suggests the presence of one or more inhibitors of fertility genes in chromosome 6DL (Martin et al., 2009). More recently, a highly fertile line with 42 chromosomes plus an extra acrocentric chromosome has been obtained (Martin et al., 2010), whose long arm is the $1 \mathrm{H}^{\text {ch }} \mathrm{S}$ chromosome, as demonstrated by molecular markers and fluorescent in situ hybridization. It seems that this chromosome originated from a deletion of the distal part of chromosome $1 \mathrm{H}^{\mathrm{ch}} \mathrm{L}$ and that the restorer gene is located on the retained segment from the $1 \mathrm{H}^{\mathrm{ch}} \mathrm{L}$ (Martin et al., 2010). The disomic addition of this acrocentric chromosome is fully fertile and thus constitutes an additional source of restoration for wheat hybrid production based on msH1 system.

On the other hand, fully fertile alloplasmic lines were also obtained (Atienza et al., 2007d). Preliminary evidence suggested that phenotypic and metabolic variations in wheat are associated with different nuclearcytoplasmic combinations (Atienza et al., 2007c; Atienza et al., 2008), including phenotypic traits such as height or quality traits like endosperm carotenoid content. In other cases, the use of either wheat or $H$. chilense cytoplasm did not result in any phenotypic variation in Tritordeum (Atienza et al., 2007e). The genetic effects of the plasmon have been studied in several species affecting different traits including yield (Loessl et al., 2000), disease or pest resistance (Voluevich and Buloichik, 1992; Matsui et al., 2002) and tolerance to abiotic stresses (Uprety and Tomar, 1993; Shonnard and Gepts, 1994; Zhang et al., 2003). Nevertheless, the most detailed studies have been performed in the Triticum-Aegilops complex (Tsunewaki et al., 1996, 2002; Tsunewaki, 2009) and in teosinte-maize combinations (Allen, 2005).

Recently, parallel transcriptomic and metabolomic analyses have been carried out on three alloplasmic lines to investigate the effect of $H$. chilense, Ae. uniaristata and Ae. squarrosa cytoplasms on nuclear-cytoplasm 
interaction with common wheat (Crosatti et al., 2010). The gas chromatography-mass spectrometer metabolic profiling of leaves revealed significant differences between the alloplasmic lines and their euplasmic control. Transcriptomic analyses using the Affimetrix $61 \mathrm{k}$ wheat gene chip showed that more than 500 genes modified their behaviour in the $H$. chilense alloplasmic line compared with the euplasmic control (Crosatti et al., 2010). Most of them encoded for chloroplast/mitochondrion localized proteins. The simultaneous consideration of transcriptomic and metabolomic data underlined that the amino-acid biosynthetic pathways are highly dependent on the nuclear-cytoplasm interaction.

In conclusion, $H$. chilense is an interesting source of variability for wheat breeding and the study of the alloplasmic lines allows us to increase our understanding of how nuclear and cytoplasmic genomes interact. Thus, this may open up new opportunities for plant improvement through cytoplasm modification.

\section{Acknowledgements}

Our work in this area is supported by grants (to S. G. A.) AGL2008-03720, and P09-AGR-4817 from Spanish Ministry of Science and Innovation, Junta de Andalucía and FEDER. C. R.-S. acknowledges financial support from CSIC (JAE-Doc program).

\section{References}

Aksyonova E, Sinyavskaya M, Danilenko N, Pershina L, Nakamura C and Davydenko O (2005) Heteroplasmy and paternally oriented shift of the organellar DNA composition in barley-wheat hybrids during backcrosses with wheat parents. Genome 48: 761-769.

Allen JO (2005) Effect of teosinte cytoplasmic genomes on maize phenotype. Genetics 169: 863-880.

Alvarez JB, Martin LM and Martin A (1999) Genetic variation for carotenoid pigment content in the amphiploid Hordeum chilense $\times$ Triticum turgidum conv. durum. Plant Breeding 118: $187-189$.

Atienza SG, Gimenez MJ, Martin A and Martin LM (2000) Variability in monomeric prolamins in Hordeum chilense. Theoretical and Applied Genetics 101: 970-976.

Atienza SG, Alvarez JB, Villegas AM, Gimenez MJ, Ramirez MC, Martin A and Martin LM (2002) Variation for the lowmolecular-weight glutenin subunits in a collection of Hordeum chilense. Euphytica 128: 269-277.

Atienza SG, Ramirez CM, Hernandez P and Martin A (2004) Chromosomal location of genes for carotenoid pigments in Hordeum chilense. Plant Breeding 123: 303-304.

Atienza SG, Avila CM, Ramirez MC and Martin A (2005a) Application of near infrared reflectance spectroscopy to the determination of carotenoid content in tritordeum for breeding purposes. Australian Journal of Agricultural Research 56: 85-89.
Atienza SG, Satovic Z, Martin A and Martin LM (2005b) Genetic diversity in Hordeum chilense Roem. et Schult. germplasm collection as determined by endosperm storage proteins. Genetic Resources and Crop Evolution 52: 127-135.

Atienza SG, Avila CM and Martin A (2007a) The development of a PCR-based marker for PSY1 from Hordeum chilense, a candidate gene for carotenoid content accumulation in tritordeum seeds. Australian Journal of Agricultural Research 58: 767-773.

Atienza SG, Ballesteros J, Martin A and Hornero-Mendez D (2007b) Genetic variability of carotenoid concentration and degree of esterification among tritordeum $(\times$ Tritordeum Ascherson et Graebner) and durum wheat accessions. Journal of Agricultural and Food Chemistry 55: 4244-4251.

Atienza SG, Martin AC and Martin A (2007c) Introgression of wheat chromosome $2 \mathrm{D}$ or $5 \mathrm{D}$ into tritordeum leads to free-threshing habit. Genome 50: 994-1000.

Atienza SG, Martin AC, Ramirez MC, Martin A and Ballesteros J (2007d) Effects of Hordeum chilense cytoplasm on agronomic traits in common wheat. Plant Breeding 126: 5-8.

Atienza SG, Ramirez MC, Martin A and Ballesteros J (2007e) Effects of reciprocal crosses on agronomic performance of tritordeum. Russian Journal of Genetics 43: 865-868.

Atienza SG, Martín A, Pecchioni N, Platani C and Cattivelli L (2008) The nuclear-cytoplasmic interaction controls carotenoid content in wheat. Euphytica 159: 325-331.

Badaeva ED, Pershina LA and Bildanova LL (2006) Cytogenetic analysis of alloplasmic recombinant lines (H. vulgare)-T. aestivum unstable in fertility and viability. Russian Journal of Genetics 42: 140-149.

Bolot S, Abrouk M, Masood-Quraishi U, Stein N, Messing J, Feuillet C and Salse J (2009) The inner circle of the cereal genomes. Current Opinion in Plant Biology 12: 119-125.

Castillo A, Budak H, Martin AC, Dorado G, Borner A, Roder M and Hernandez P (2010) Interspecies and intergenus transferability of barley and wheat D-genome microsatellite markers. Annals of Applied Biology 156: 347-356.

Cherif-Mouaki S, Said M, Alvarez JB and Cabrera A (2011) Sub-arm location of prolamin and EST-SSR loci on chromosome $1 \mathrm{H}^{\mathrm{ch}}$ from Hordeum chilense. Euphytica. doi 10.1007/ s10681-010-0268-y.

Chung S-M and Staub JE (2003) The development and evaluation of consensus chloroplast primer pairs that possess highly variable sequence regions in a diverse array of plant taxa. Theoretical and Applied Genetics 107: 757-767.

Crosatti C, Quansah L, Atienza SG, Mare C, Fait A and Cattivelli L (2010) Exploitation of diversity in nuclear-cytoplasm interaction using alloplasmic wheat lines. 2nd International Symposium on Genomics of Plant Genetic Resources, Bologna, Italy, p. 86.

Hagras AAA, Kishii M, Sato K, Tanaka $\mathrm{H}$ and Tsujimoto $\mathrm{H}$ (2005a) Extended application of barley EST markers for the analysis of alien chromosomes added to wheat genetic background. Breeding Science 55: 335-341.

Hagras AAA, Kishii M, Tanaka H, Sato $K$ and Tsujimoto $H$ (2005b) Genomic differentiation of Hordeum chilense from $H$. vulgare as revealed by repetitive and EST sequences. Genes and Genetic Systems 80: 147-159.

Inostroza L, del Pozo A, Matus I, Castillo D, Hayes P, Machado S and Corey A (2009) Association mapping of plant height, yield, and yield stability in recombinant chromosome substitution lines (RCSLs) using Hordeum vulgare subsp. spontaneum as a source of donor alleles in a Hordeum 
vulgare subsp. vulgare background. Molecular Breeding 23: $365-376$.

Kihara H (1951) Substitution of nucleus and its effects on genome manifestations. Cytologia 16: 177-193.

Laser B, Mohr S, Odenbach W, Oettler G and Kück U (1997) Parental and novel copies of the mitochondrial orf25 gene in the hybrid crop-plant triticale: predominant transcriptional expression of the maternal gene copy. Current Genetics 32: 337-347.

Loessl A, Goetz M, Braun A and Wenzel G (2000) Molecular markers for cytoplasm in potato: male sterility and contribution of different plastid-mitochondrial configurations to starch production. Euphytica 116: 221-230.

Martin AC (2009) Desarrollo de un nuevo sistema de androesterilidad en trigo (Triticum aestivum L.) utilizando la especie Hordeum chilense Roem. et Schultz. PhD Thesis, University of Córdoba, Spain.

Martin A and Chapman V (1977) A hybrid between Hordeum chilense and Triticum aestivum. Cereal Research Communications 5: 365-368.

Martin A, Martín LM, Cabrera A, Ramírez MC, Giménez MJ, Rubiales P, Hernández P and Ballesteros J (1998) The potential of Hordeum chilense in breeding Triticeae species. In: Jaradat AA (ed.) Triticeae III. Enfield, CT: Science Publications, pp. 377-386.

Martin A, Alvarez JB, Martin LM, Barro F and Ballesteros J (1999) The development of tritordeum: a novel cereal for food processing. Journal of Cereal Science 30: 85-95.

Martin AC, Atienza SG and Barro F (2008a) Use of ccSSR markers for the determination of the purity of alloplasmic wheat in different Hordeum cytoplasms. Plant Breeding 127: $470-475$.

Martin AC, Atienza SG, Ramirez MC, Barro F and Martin A (2008b) Male fertility restoration of wheat in Hordeum chilense cytoplasm is associated with $6 \mathrm{H}(\mathrm{ch}) \mathrm{S}$ chromosome addition. Australian Journal of Agricultural Research 59: 206-213.

Martin AC, Atienza SG, Ramirez MC, Barro F and Martin A (2009) Chromosome engineering in wheat to restore male fertility in the msH1 CMS system. Molecular Breeding 24: 397-408.

Martin AC, Atienza SG, Ramírez M, Barro F and Martin A (2010) Molecular and cytological characterization of an extra acrocentric chromosome that restores male fertility of wheat in the msH1 CMS system. Theoretical and Applied Genetics 121: $237-240$.

Matsui K, Yoshida M, Ban T, Komatsuda T and Kawada N (2002) Role of male-sterile cytoplasm in resistance to barley yellow mosaic virus and Fusarium head blight in barley. Plant Breeding 121: 237-240.

Matus I, Corey A, Filichkin T, Hayes PM, Vales MI, Kling J, Riera-Lizarazu O, Sato K, Powell W and Waugh R (2003) Development and characterization of recombinant chromosome substitution lines (RCSLs) using Hordeum vulgare subsp. spontaneum as a source of donor alleles in a Hordeum vulgare subsp. vulgare background. Genome 46: 1010-1023.
Nasuda S, Kikkawa Y, Ashida T, Rafiqul Islam AKM, Sato K and Endo TR (2005) Chromosomal assignment and deletion mapping of barley EST markers. Genes and Genetic Systems 80: 357-366.

Rodriguez-Suarez C, Gimenez MJ and Atienza SG (2010) Progress and perspectives for carotenoid accumulation in selected Triticeae species. Crop Pasture Science 61: $743-751$.

Said M and Cabrera A (2009) A physical map of chromosome $4 \mathrm{H}^{\mathrm{ch}}$ from $H$. chilense containing SSR, STS and EST-SSR molecular markers. Euphytica 167: 253-259.

Shonnard GC and Gepts P (1994) Genetics of heat tolerance during reproductive development of common bean. Crop Science 34: 1168-1175.

Soliman K, Fedak G and Allard RW (1987) Inheritance of organelle DNA in barley and Hordeum $\times$ Secale intergeneric hybrids. Genome 29: 867-872.

Tanksley SD and McCouch SR (1997) Seed banks and molecular maps: unlocking genetic potential from the wild. Science 277: 1063-1066.

Tsunewaki K (2009) Plasmon analysis in the Triticum-Aegilops complex. Breeding Science 59: 455-470.

Tsunewaki K, Wang G-Z and Matsuoka Y (1996) Plasmon analysis of Triticum (wheat) and Aegilops. 1. Production of alloplasmic common whets and their fertilities. Genes and Genetic Systems 71: 293-311.

Tsunewaki K, Wang G-Z and Matsuoka Y (2002) Plasmon analysis of Triticum (wheat) and Aegilops. 2. Characterization and classification of 47 plasmons based on their effects on common wheat phenotype. Genes and Genetic Systems 77: 409-427.

Uprety DC and Tomar VK (1993) Photosynthesis and drought resistance of Brassica carinata and its parent species. Photosynthetica 29: 321-327.

van Ginkel M and Ogbonnaya F (2007) Novel genetic diversity from synthetic wheats in breeding cultivars for changing production conditions. Field Crops Research 104: 86-94.

Vaz Patto MC, Aardse A, Buntjer J, Rubiales D, Martin A and Niks RE (2001) Morphology and AFLP markers suggest three Hordeum chilense ecotypes that differ in avoidance to rust fungi. Canadian Journal of Botany 79: $204-213$.

Voluevich EA and Buloichik AA (1992) Nuclear-cytoplasmic interactions in wheat resistance to fungi pathogens: V. Quantitative resistance of alloplasmic line seedlings of Penjamo 672 variety to powdery mildew. Genetika 28: 82-88.

Warburton M, Crossa J, Franco J, Kazi M, Trethowan R, Rajaram S, Pfeiffer W, Zhang P, Dreisigacker S and Ginkel M (2006) Bringing wild relatives back into the family: recovering genetic diversity in CIMMYT improved wheat germplasm. Euphytica 149: 289-301.

Zhang A, Yu F and Zhang F (2003) Alien cytoplasm effects on phytosiderophore release in two spring wheats (Triticum aestivum L.). Genetic Resources and Crop Evolution 50: $767-772$. 